\title{
The Use of Supplement Blocks for Sheep Grazing Dry, Annual Pastures in California
}

\section{E.J. DEPETERS, M.R. DALLY, A.A. ALWASH, AND P. THERKELSEN-TUCKER}

Abstract

The objective of this study was to evaluate the use of supplement blocks on body weight change, blood parameters, and lambing performance of ewes grazing dry, annual grasses during the summer prior to and during breeding. Two experiments were conducted in successive years to compare performance of unsupplemented control (C) and supplemented (S) Targhee ewes. In the first season, yearling ewes were used while aged ewes ( 2 or 4 years) were used during the second season. During the first year (1980), supplemented ewes lost less body weight during the dry grazing season than $\mathrm{C}$ ewes. However, no lambing performance difference was found between $C$ and $S$ groups. During the second year (1981), supplemented ewes maintained their body weight over the summer while $C$ ewes lost weight. In addition, lambing performance (multiple births) was higher for $S$ than $C$ ewes. Supplementation of ewes with blocks containing molasses, urea, protein, and minerals required little labor input. However, based on lambing performance, it is unlikely that supplementation would be economically profitable under the range conditions utilized in these trials.

Sheep grazing pastures containing dried, annual grasses during the summer show a progressive decline in body weight and produce fewer lambs when exposed to rams in the fall (Torell et al. 1972a). In the north coastal areas of California, flushing ewes to improve lambing performance has been practiced by commercial sheep producers maintaining flocks on dry summer range forage. While this practice has increased the incidence of multiple births (Torell et al. 1972a, b), flushing can be expensive in terms of feed and labor required.

Forage available during the dry grazing period is low in nitrogen and high in fiber content. Supplementing animals grazing forage low in nitrogen with urea and molasses has been found to result in reduced live weight losses compared with unsupplemented animals (Beames and Morris 1965, Entwistle and Knights 1974, Mulholland and Coombe 1979). In contrast, Beasley and McMeniman (1976) reported no advantage in urea and molasses supplementation. Forages containing below $1 \%$ nitrogen are reported to have reduced efficiency of cellulose breakdown in the reticulo-rumen (Pigden and Heaney 1969). Therefore, attempts have been made to supplement low nitrogen diets with urea. Nitrogen from urea can be used for microbial growth if adequate energy is available resulting in improved fiber digestion. However, there is a limit to the amount of nonprotein nitrogen that can be utilized by the microbial population (Satter and Roffler 1975).

The objective of the present study was to evaluate hard supplement blocks as a source of nitrogen, energy, and minerals and their effects on live weight change of ewes grazing summer range and their subsequent lambing performance.

\section{Materials and Methods}

Two experiments were conducted at the Hopland Field Station to evaluate the use of a hard supplement block on body weight and lambing performance of ewes grazing dry annual California range land for 2 seasons. Ingredient and chemical compositions of the supplement block used during both grazing seasons are shown in Table 1. The block was composed predominately of molasses and

The authors are assistant professor, research associate, visiting scientist from the University of Baghdad, and graduate student, Department of Animal Science, University of California, Davis 95616

The authors wish to thank Benton Feed Yard of Walnut, Calif., for supplying the supplement blocks and D.T. Torell for his help

Manuscript accepted October 18, 1984.
Table 1. Ingredient and chemical composition of supplement block fed to range sheep.

\begin{tabular}{lc}
\hline \hline & Block \\
\hline & $\%$ DM \\
Ingredients & 66.96 \\
Molasses solids & 14.0 \\
Cottonseed meal & 6.1 \\
Urea & 6.0 \\
Flour, bakery & 2.4 \\
Fat & 2.0 \\
Fish solubles & 1.3 \\
Rock phosphate & 1.0 \\
Lime & .2 \\
Zinc sulphate & .04 \\
Copper sulphate & \\
Composition & \\
Total nitrogen (N) & 5.0 \\
Nonprotein-N & 3.4 \\
Fat & 2.3 \\
Ash & 13.9 \\
Dry matter & 90.2 \\
\hline
\end{tabular}

contained nitrogen from protein and nonprotein sources and minerals.

Experiment 1. During the first grazing season (6/80 to $10 / 80) 76$ yearling Targhee ewes were randomly assigned to $l$ of 2 treatments. Treatments consisted of either no supplementation (C) or supplementation (S) with a hard molasses-nitrogen-mineral block during the summer dry grass grazing period. Animals were weighed and assigned to treatments on $6 / 28 / 80$ and were allotted to 1 of 2 pastures. The range pastures consisted of annual grasses and forbs (Van Dyne and Heady 1965) which were already dry at the initiation of the study. Grasses included soft chess (Bromus mollis), slender oat (Avena barbata), silver hairgrass (Aira caryophyllea), annual fescues (Festuca spp.), ripgut grass (Bromus rubens), and medusahead (Taeniatheran asperum). Forbes included broadleaf filaree (Erodium botrys), true clover (Trifolium spp.), and Italian thistle (Carduus pycnocephalus).

Ewes were weighed monthly. Determination of plasma glucose and urea nitrogen was made by jugular blood samples collected from all ewes prior to monthly weighing. Blood was collected in 10 $\mathrm{ml}$ vacutainers containing disodium EDTA and sodium fluoride and was centrifuged at $3000 \mathrm{rpm}$ for 10 minutes. Plasma was frozen for later analysis. Fecal samples from 10 ewes in each group were also collected at weighing. Because of the difficulty in obtaining sufficient sample size from each animal, fecal samples were composited (many sheep defecated while being moved through the corral area, making sample collection difficult). Groups were rotated between pastures to reduce pasture effects following monthly weighing of sheep. Samples of diets selected by grazing sheep were obtained using 6 esophageally fistulated sheep. Three animals per pasture were used. Samples were collected at $600 \mathrm{~h}$ for 30 minutes 1 day per month. Forage samples were dried, ground, and analyzed individually.

Supplement blocks were placed in wooden mangers in the pasture at the bedding area. Blocks were weighed initially and at approximately weekly intervals thereafter. Fresh blocks were provided when necessary until $10 / 29 / 80$, and samples taken for chemical analysis. All ewes were shorn on $7 / 14 / 80$ and weighed before 
and after shearing. Two Targhee rams per group were placed with ewes for mating for $\mathbf{4 0}$ days, beginning $8 / 28 / 80$. All ewes were barn lambed to facilitate collection of lambing data.

Experiment 2. Aged Targhee ewes (106) were allotted to 1 of 2 treatment groups (53 ewes/group) as described in Experiment 1 based on age of ewe ( 2 vs 4 year old) and previous lambing performance (single vs multiple births). In an attempt to advance onset of the breeding season, vasectomized rams were placed with both groups between $7 / 23$ to $8 / 9 / 81$. Two intact Targhec rams per group were added for mating and remained with ewes for 40 days, beginning 8/9/81. Supplement blocks were the same as used in Experiment 1. Blocks were offered until 10/14/81. Animals were weighed monthly and jugular blood samples collected randomly from 20 cwes per group prior to wcighing. Samples of diets selected by grazing ewes were obtained using 2 esophageally fistulated animals per pasture (4). Samples were collected at $600 \mathrm{~h}$ for 30 minutes 1 day per month. Forage samples were dried, ground, and analyzed individually. Pastures were the same as used in Experiment 1. Supplement blocks were sampled and weighed weekly. Fecal samples were randomly collected from 10 ewes per group and prepared as in Experiment 1. All ewes were barn lambed for collection of lambing data.

Esophageal forage and fecal samples were analyzed for dry matter (DM), nitrogen $(\mathrm{N})$, and ash according to the specifications provided by the Association of Official Analytical Chemists (1975). Acid detergent fiber (ADF), cellulose, lignin, and neutral detergent fiber (NDF) were determined by procedures described by Goering and Van Soest (1970) and in vitro disappearance of organic matter (IVOMD) according to Tilley and Terry (1963). Plasma was analyzed for glucose and urea nitrogen on a Technicon Auto Analyzer by method N-2b and N-1b, respectively. Supplement block samples were analyzed for total nitrogen and nonprotein nitrogen (Association of Official Analytical Chemists 1975).

Body weight and plasma urea nitrogen and glucose for each weigh date were analyzed for differences by $t$-test (Dixon et al. 1981). Lambing performance was analyzed as categorial data because the variables are discrete (Dixon et al. 1981). Statistical model included treatment as a factor in Experiment 1 and 2. Age of ewe was initially included in the model for Experiment 2 but was found to be not significant and therefore only treatment was included as a factor. Individual animal data during each experiment were used for statistical analysis since groups were not replicated. It was assumed that all animals had equal access to blocks and therefore individual animal data were used, although the authors acknowledge the shortcomings of such analysis. Chemical compositions of esophageal forage and fecal grab samples were not statistically analyzed.

\section{Results and Discussion}

During Experiment 1, supplement intakes were low during the first 8 weeks of the trial (Fig. 1). As the trial progressed, muzzle stains indicated an increasing number of ewes consumed the supplement. From the end of August to the end of October, supplement intake averaged $130 \mathrm{~g} \mathrm{DM} /$ ewe/day. This provided $6.5 \mathrm{~g}$ $\mathrm{N} /$ ewe/day, of which $68 \%$ of the nitrogen was from nonprotein sources. Approximately $40 \%$ of the ewe's daily $\mathrm{N}$ requirement was supplied by block supplementation during this period for ewes averaging $47 \mathrm{~kg}$ body weight (National Research Council 1975). Yearling ewes were slow to adapt to the blocks even though blocks were available at all times. Intake of supplement increased as the trial progressed. Quality of forage selected by grazing animals varied little during the grazing period (Table 2). Nitrogen content was low and fibcr content high for all samples for both pastures.

No difference in body weight between the two groups was observed except on $10 / 22 / 80$, at which time $S$ ewes weighed more than $\mathrm{C}$ ewes (Fig. 2). This time period of improved body weight coincides with the time of highest supplement intake. However, ewes in both groups lost body weight from the end of July through

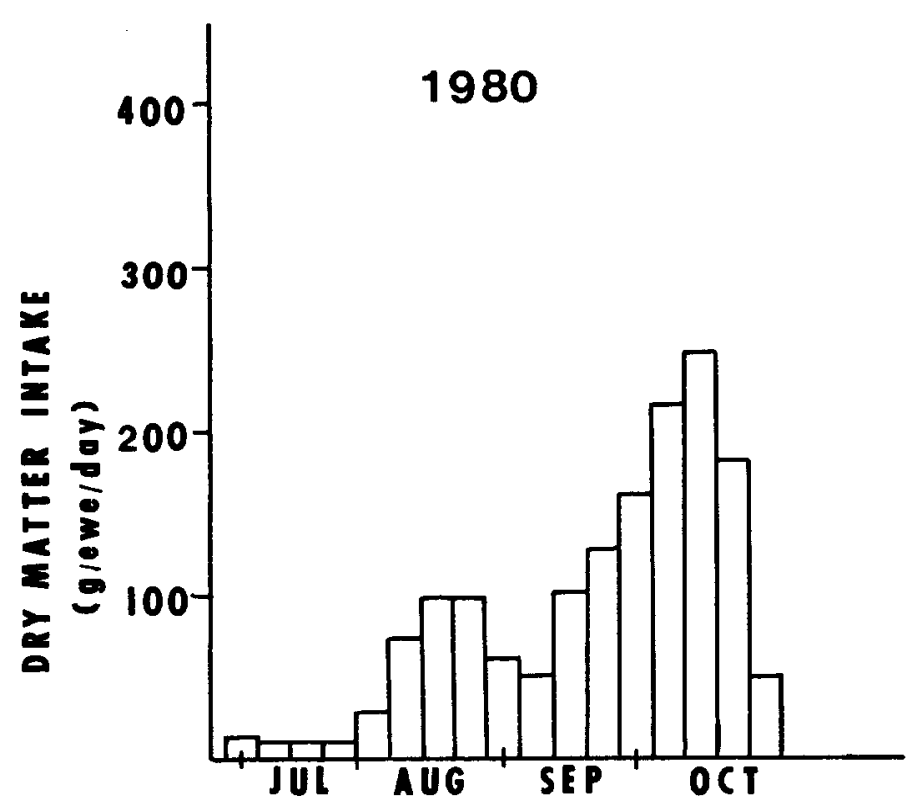

I IM E

Fig. 1. Daily intake of supplement (Exp. 1).

Table 2. Chemical composition of esophageal forage samples during the grazing season (Exp. 1).

\begin{tabular}{lrrrrrrr}
\hline & \multicolumn{3}{c}{ Pasture $^{c} 1$} & & \multicolumn{3}{c}{ Pasture $^{\mathrm{c}} 2$} \\
Date $^{\mathrm{a}}$ & $7 / 31$ & $8 / 28$ & $9 / 24$ & & $7 / 31$ & $8 / 28$ & $9 / 24$ \\
\hline ltem $^{\mathrm{b}}$ & 1.1 & 1.3 & 1.2 & & 1.1 & 1.2 & 1.2 \\
Nitrogen (\%) & 50.6 & 7.7 & 52.2 & & 8.6 & 9.1 & 50.7 \\
ADF (\%) & 62.0 & 61.5 & 67.8 & & 65.0 & 63.9 & 70.2 \\
NDF (\%) & 9.4 & 6.2 & 9.4 & & 7.5 & 6.9 & 8.0 \\
Cellulose (\%) & 8.4 & 8.8 & 9.3 & & 8.6 & 9.6 & 9.3 \\
Lignin (\%) & 52.0 & 53.1 & 50.0 & & 50.1 & 49.3 & 49.2 \\
IVOMD (\%) & &
\end{tabular}

${ }^{\mathrm{a}} S$ ewes began grazing past ure $L$ on $7 / 31 / 80$, were switched to pasture 2 until $8 / 28 / 80$ when they were returned to pasture 1 , etc.

${ }^{b}$ Values are expressed on an organic matter basis.

Pasture I was 30.8 ha and pasture 2 was $33.6 \mathrm{~h}$

breeding.

During the second experiment, mature ewes consumed more supplement during the early weeks of the trial than yearling ewes. Molasses stains on muzzles were used as an indication that all ewes except one consumed the block. Quality of forage selected by grazing animals did not change during the grazing period (Table 3 ). Although the same pastures were used in hoth years, higher $\mathrm{N}$ and lignin contents were observed in the second grazing season. The reason for the higher lignin content is uncertain. It may have contributed to the slightly lower in vitro disapperance of organic matter.

Body weight for $\mathrm{S}$ ewes during the second grazing season was greater $(P<.05)$ than $C$ ewes only at the last 2 weighing dates (Fig 4). Weight gain for $S$ ewes coincided with the period of greatest supplement intake. Intake averaged $301 \mathrm{~g} \mathrm{DM} /$ ewe/day supplying $15 \mathrm{~g} \mathrm{~N} /$ ewe daily or approximately $100 \%$ of the ewe's daily requirement based on an average body weight of $54 \mathrm{~kg}$ (National Research Council 1975). Even though $\mathrm{S}$ ewes lost body weight during the last period of the trial, final body weight was greater $(P<.05)$ for $\mathrm{S}$ than for $\mathrm{C}$ ewes. Unsupplemented $\mathrm{C}$ ewes lost a total of $5 \mathrm{~kg}$ of body weight per ewe over the grazing season while $S$ ewes maintaincd initial body weight. Supplemented ewes gained body 
Table 3. Chemical composition of esophageal forage samples during the second grazing season (Exp. 2).

\begin{tabular}{|c|c|c|c|c|c|c|c|c|}
\hline \multirow[b]{2}{*}{ Date $^{\mathbf{a}}$} & \multicolumn{4}{|c|}{ Pasture I } & \multicolumn{4}{|c|}{ Pasture 2} \\
\hline & $6 / 23$ & $7 / 21$ & $8 / 26$ & $9 / 23$ & $6 / 23$ & $7 / 21$ & $8 / 26$ & $9 / 23$ \\
\hline \multicolumn{9}{|l|}{$\overline{\text { ltem }^{b}}$} \\
\hline Nitrogen $(\%)$ & 1.9 & 1.3 & 1.9 & 1.0 & 1.7 & 1.1 & 1.6 & 1.7 \\
\hline $\operatorname{ADF}(\%)$ & 39.3 & 53.2 & 41.6 & 52.8 & 36.4 & 49.8 & 45.2 & 54.5 \\
\hline NDF $(\%)$ & 57.1 & 70.4 & 49.3 & 74.9 & 55.1 & 74.2 & 56.7 & 59.0 \\
\hline Cellulose $(\%)$ & 23.8 & 36.7 & 18.9 & 43.7 & 22.7 & 40.2 & 27.4 & 29.1 \\
\hline Lignin $(\%)$ & 13.7 & 13.3 & 21.5 & 6.3 & 12.5 & 6.9 & 17.0 & 23.6 \\
\hline $\operatorname{IVOMD}(\%)$ & 39.6 & 48.2 & 37.0 & 52.1 & 39.2 & 53.6 & - & 40.3 \\
\hline
\end{tabular}

${ }^{\mathrm{a} S} \mathrm{~S}$ ewes began grazing pasture 1 on $6 / 23 / 81$, were switched to pasture 2 on $7 / 21 / 81$, etc.

${ }^{b}$ Values are expressed on an organic matter basis.

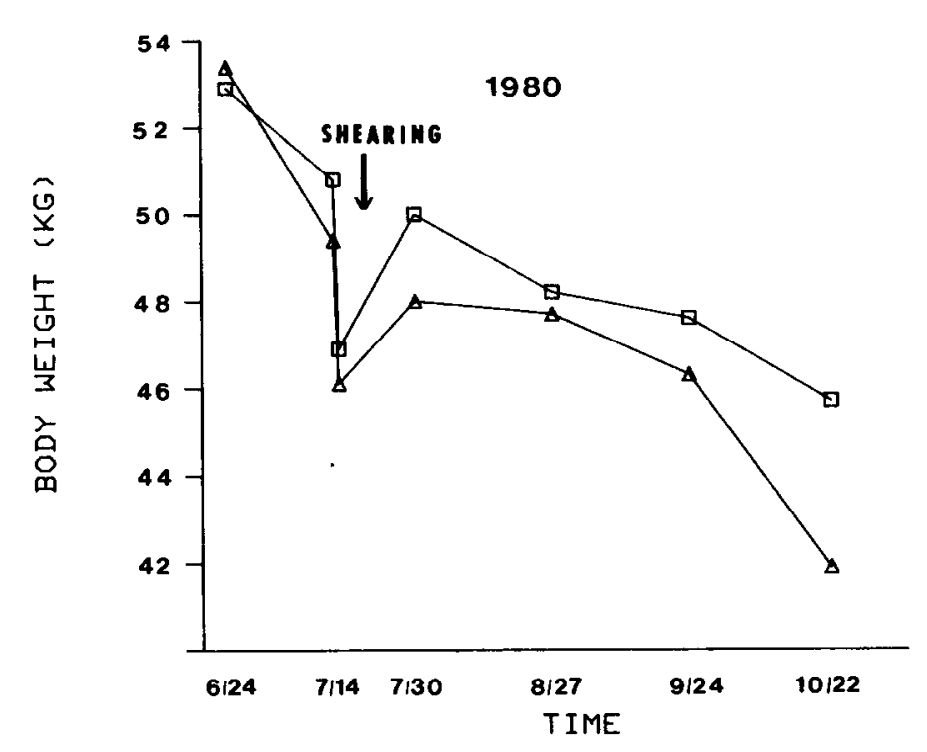

Fig. 2. Monthly body weight control $(\Delta \Delta)$ and supplemented $(\square-\square)$ ewes (Exp. 1).

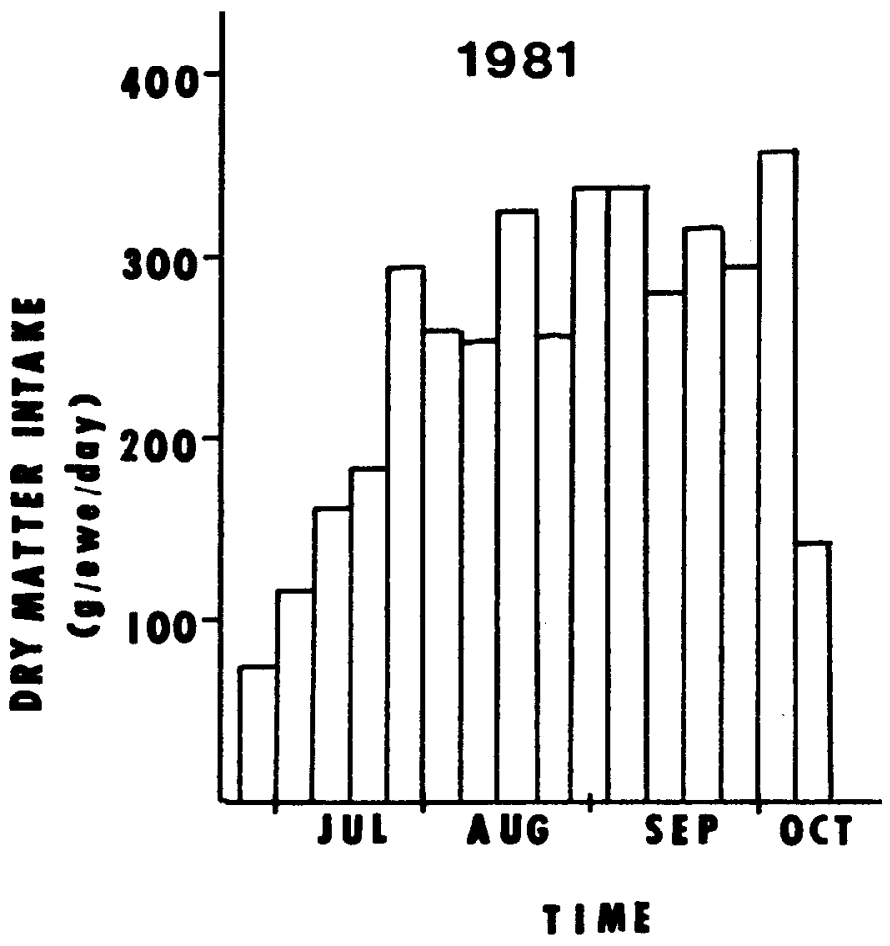

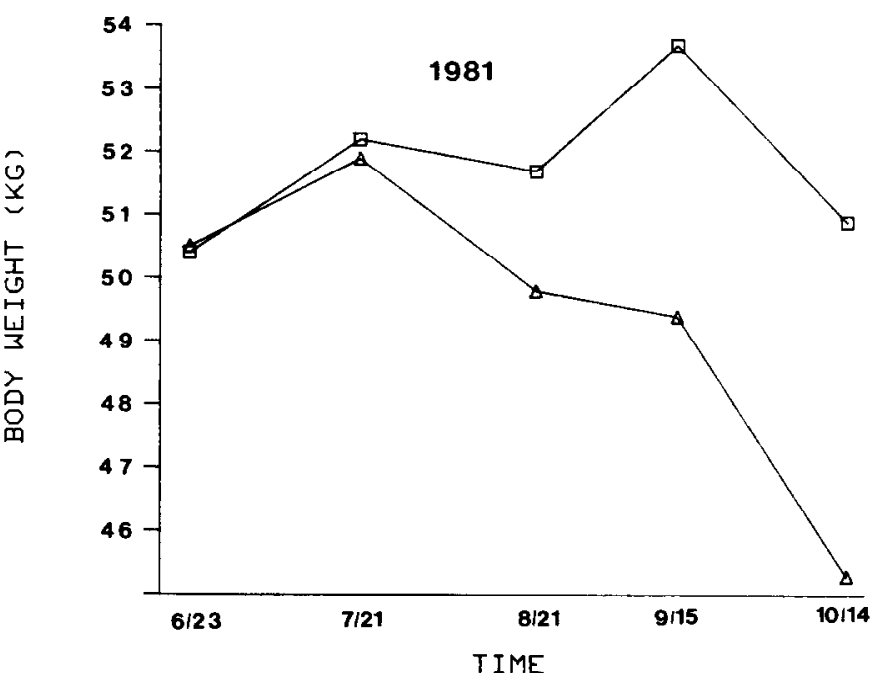

Fig. 4. Monthly body weight control $(\Delta \Delta)$ and supplemented ( $\square-\square)$ ewes (Exp. 2).

weight during mating while $C$ ewes lost weight.

In Experiment 1 no difference was found between groups in the plasma glucose levels at the first sample date, but at subsequent sampling dates plasma glucose was higher $(P<.05)$ for ewes $(S)$ receiving the supplement block (Table 4 ). A similar pattern was observed during the second grazing season where plasma glucose concentrations on July 21 were found not to differ, but at subsequent dates were higher $(P<.05)$ for $\mathrm{S}$ than for $\mathrm{C}$ ewes. Plasma urea nitrogen (PUN) in Experiment 1 was lower $(P<.05)$ for $S$ than for $C$ ewes at the first sampling period (lable 4). However, at subsequent samplings $\mathrm{S}$ ewes had higher PUN concentrations $(P<.05)$ than their unsupplemented counterparts. During the second grazing season PUN was greater for $\mathrm{S}$ than for $\mathrm{C}$ ewes at all sampling dates.

Lambing performance of yearling ewes during the first season was not affected by supplementation (Table 5). Lambing percent for ewes present at lambing was 96 and $109 \%$ for $\mathrm{C}$ and $\mathrm{S}$ groups, respectively. No difference in the proportion of multiple births between groups was found. Observed lambing performance and number of dry ewes were similar to values reported previously at this station (Torell et al. 1972b).

Lambing performance for aged ewes during the second grazing season was affected by supplementation. Ewes receiving the supplement produced more twins $(P<.05)$ than unsupplemented ewes (Table 5). There were no multiple births among $\mathrm{C}$ ewes. Although lambing performance was improved for $S$ ewes, performance was below that observed previously for ewes fed in drylut (Torell et al. 1972b) or supplemented with alfalfa pellets while grazing dry, annual grass (Torell et al. 1972a). Performance for C ewes was poor and below levels previously observed at this station for range

Fig. 3. Daily intake of supplement (Exp. 2). 
Table 4. Plasma urea nitrogen (PUN) and glucose of ewes during the first (Exp. 1) and second (Exp. 2) graxing season.

\begin{tabular}{|c|c|c|c|c|c|c|c|c|c|}
\hline \multirow[b]{3}{*}{ Group } & \multicolumn{4}{|c|}{ Exp. 1} & & \multicolumn{4}{|c|}{ Exp. 2} \\
\hline & \multicolumn{2}{|c|}{ PUN' } & \multicolumn{2}{|c|}{ Glucose ${ }^{I}$} & & \multicolumn{2}{|c|}{ PUN } & \multicolumn{2}{|c|}{ Glucose } \\
\hline & $\mathrm{C}$ & $\mathrm{S}$ & $\mathrm{C}$ & $\mathrm{S}$ & & $\mathrm{C}$ & $\mathrm{S}$ & $C$ & $\mathrm{~S}$ \\
\hline $\begin{array}{l}\text { Date } \\
7 / 30 / 80 \\
8 / 27 / 80 \\
9 / 24 / 80\end{array}$ & $\begin{array}{l}8.4^{\mathrm{a}} \\
6.8^{\mathrm{a}} \\
6.8^{\mathrm{a}}\end{array}$ & $\begin{array}{r}7.6^{\mathrm{b}} \\
10.4^{\mathrm{b}} \\
8.2^{\mathrm{b}}\end{array}$ & $\begin{array}{l}54.2 \\
50.3^{\mathrm{a}} \\
58.7^{\mathrm{a}}\end{array}$ & $\begin{array}{l}56.7 \\
54.7^{\mathrm{b}} \\
64.4^{\mathrm{b}}\end{array}$ & $\begin{array}{c}\text { Date } \\
7 / 21 / 81 \\
8 / 21 / 81 \\
9 / 15 / 81\end{array}$ & $\begin{array}{l}6.4^{\mathrm{a}} \\
5.7^{\mathrm{a}} \\
4.6^{\mathrm{a}}\end{array}$ & $\begin{array}{r}10.2^{b} \\
9.4^{b} \\
7.7^{b}\end{array}$ & $\begin{array}{l}46.2 \\
50.4^{\mathrm{a}} \\
50.1^{\mathrm{a}}\end{array}$ & $\begin{array}{l}49.7^{b} \\
56.5^{\mathrm{b}} \\
53.3^{\mathrm{b}}\end{array}$ \\
\hline
\end{tabular}

Values expressed as $\mathrm{mg} / 100 \mathrm{ml}$.

, Means with different superscript between $\mathrm{C}$ and $\mathrm{S}$ within a blood parameter differ $P<.05$.

Table 5. Lambing performance of ewes in Exp. 1 and Exp. 2.

\begin{tabular}{|c|c|c|c|c|}
\hline \multirow[b]{2}{*}{ Group } & \multicolumn{2}{|c|}{ Exp. 1} & \multicolumn{2}{|c|}{ Exp. 2} \\
\hline & $\mathrm{C}$ & $\mathbf{S}$ & $\mathrm{C}$ & $\mathbf{S}$ \\
\hline \multicolumn{5}{|l|}{ Measurement } \\
\hline No. ewes & 28 & 34 & 31 & 49 \\
\hline Lambing $\%^{1}$ & 96.4 & 108.8 & 87.1 & 100.0 \\
\hline Lambing $\%^{2}$ & 112.5 & 115.6 & $100.0^{\mathrm{a}}$ & $116.7^{b}$ \\
\hline$\%$ dry ewes & 14.3 & 5.9 & 12.9 & 14.3 \\
\hline$\%$ multiple births & 12.5 & 15.6 & $0^{\mathbf{a}}$ & $16.7^{b}$ \\
\hline Lambing date $(d)^{3}$ & 221 & 221 & 223 & 221 \\
\hline
\end{tabular}

'Lambs born $\times 100 /$ ewe present at lambing.

${ }^{2}$ Lambs born $\times 100 /$ ewe lambing.

${ }^{3}$ Lambing date is days at lambing where day $1=\mathrm{July} 1$.

a, Means with different superscripts differ $P<.05$.

bred ewes (Torell et al. 1972a). However, in the present work, breeding took place earlier in the breeding season.

Animal losses for both experiments was similar. Coyote and dog kills accounted for some losses, although other animals were missing and no determination of loss could be made. During Experiment 2, twelve $C$ ewes were eliminated from the study as a result of being bred out of schedule by a ram gaining access to the pasture.

Composite fecal grab samples were collected 3 times during each grazing season. During the first grazing season fecal $\mathbf{N}$ levels averaged 1.7 and $1.8 \%$ for $\mathrm{C}$ and $\mathrm{S}$ groups, respectively. For the second grazing season fecal $\mathbf{N}$ levels were slightly higher for supplemented ewes $(2.3 \%)$ compared with control ewes $(1.7 \%)$. The higher fecal $\mathbf{N}$ content of $\mathbf{S}$ ewes may indicate improved pasture digestibility (Gartner and Murphy 1972). Allden and Jennings (1969) proposed that fecal $\mathrm{N}$ values below 1.4-1.5\% may indicate that grazing animals are marginal in dietary $\mathbf{N}$. However, response to urea supplementation has been reported for cattle fed diets containing 1.6\% N (Langlands and Donald 1978). These authors proposed that the dietary $\mathrm{N}$ level requiring supplemental $\mathrm{N}$ is influenced by organic matter digestibility and rumen degradability of the protein. In the present work, fecal $\mathrm{N}$ of composite samples is presented only in observations.

Beames and Morris (1965) reduced body weight losses of ewes receiving pasture hay $(0.6 \% \mathrm{~N})$ by supplementation with salt blocks containing $10 \%$ molasses and either 20 or $35 \%$ urea. Similarly, Mulholland Coombe (1979) reduced body weight loss with ureamolasses supplements. The favorable responses to supplementation during the second grazing season may be related to either $\mathrm{N}$ or energy (molasses) intake. Although responses to molasses-urea blocks have been attributed to the $\mathrm{N}$ fraction, Nolan et al. (1975) provided evidence that the reduction in weight loss by sheep was due largely to molasses intake. It is not possible to separate the contribution of $\mathrm{N}$ and energy in the present experiments. In addition, the blocks provided minerals which may influence animal performance.

The reason for the variation in block acceptance across seasons is not clear. Yearling ewes in the first year were much slower to accept the blocks. Other workers have reported variation in acceptability of urea-molasses supplements (Nolan et al. 1975, Mulholland and Coombe 1979, Lobato and Pearce 1980a). Intake of blocks was greater earlier and throughout the second grazing season. Although some ewes in the $\mathrm{S}$ group were experienced with blocks, Lobato and Pearce (1980b) reported that previous experience with molasses-urea blocks did not consistently affect initial intake with sheep.

In summary, supplement blocks containing molasses, $\mathrm{N}$, and minerals reduced body weight loss and did not affect reproductive performance of yearling ewes during the first experiment. Supplementation of aged ewes maintained initial body weight and improved reproductive performance during the second grazing season. However, the cost of supplementation may not be cost effective compared with flushing ewes just prior to and during breeding with concentrate or forage. Block supplementation may be cost effective if death losses of ewes are reduced during summer grazing of annual ranges, which could not be measured in the present experiments.

\section{Literature Cited}

Allden, W.G., and A.C. Jennings. 1969. The summer nutrition of immature sheep: the nitrogen excretion of grazing sheep in relation to supplements of a vailable energy and protein in a Mediterranean environment. Aust. J. Agr. Res. 20:125.

Association of Official Analytical Chemist. 1975. Official methods of analysis, 12th ed. Ass. Offic. Anal. Chem., Washington D.C.

Beames, R.M., and J.G. Morris. 1965. Effect of salt/urea blocks on bodyweight, body composition and wool production of sheep fed low-protein native grass hay. Queensl. J. Agr. Anim. Sci. 22:369.

Beasley, P.S., and N.P. McMeniman. 1976. The effect of urea molasses supplementation on live weight, wool production and reproductive performance of Merino ewes grazing poor quality native pasture. Queensl. J. Agr. Anim. Sci. 33:223.

Dixon, W.J., M.B. Brown, L. Engelman, J.W. Frane, M.A. Hill, R.I. Jennrich, and J.D. Toporek. 1981. BMDP statistical software. University of California Press, Berkeley.

Entwistle, K.W., and G. Knights. 1974. The use of urea-molasses supplements for sheep grazing semi-arid tropical pastures. Aust. J. Exp. Agr. 14:17.

Gartner, R.J.W., and G.M. Murphy. 1972. Blood and fecal parameters of Merino ewes grazing Mitchell grass pastures when supplemented with urea, phosphorus and vitamins. Proc. Aust. Soc. Anim. Prod. 9:241.

Goering, H.K., and P.J. Van Soest. 1970. Forage fiber analysis. USDA Agr. Handbk. 379.

Langlands, J.P., and G.E. Donald. 1978. The nutrition of ruminants grazing native and improved pastures. II. Responses of grazing cattle to molasses and urea supplementation. Aust. J. Agr. Res. 29:863.

Lobato, J.F.P., and G.R. Pearce. 1980a. Responses to molasses-urea blocks of grazing sheep and sheep in yards. Aust. J. Exp. Agr. Anim. Husb. 20:417.

Lobato, J.F.P., and G.R. Pearce. 1980b. Effects of some management procedures on the responses of sheep to molasses-urea blocks. Aust. J. Exp. Agr. Anim. Husb. 20:422.

Mulholland, J.G., and J.B. Coombe. 1979. Supplementation of sheep grazing wheat stubble with urea, molasses and minerals: quality of diet, intake of supplements and animal response. Aust. J. Exp. Agr. Anim. Husb. 19:23. 
Nolan, J.V., B.W. Norton, R.W. Murray, F.M. Ball, F.B. Roseby, W. Rohan-Jones, M.K. Hill, and R.A. Leng. 1975. Body weight and wool production in grazing sheep given access to a supplement of urea and molasses: intake of supplement/response relationships. J. Agr. Sci. (Camb.) 84:39:

Nat. Res. Council. 1975. Nutrient requirements of Domestic Animals, No. 5. Nutrient Requirements of Sheep. Fifth Revised Ed. Nat. Acad. Sci. Nat. Res. Council, Washington, D.C.

Pigden, W.J., and D.P. Heaney. 1969. Lignocellulose in ruminant nutrition. In: R.F. Gould (Fd), Celluloses and their Applications. Advances in Chemistry Series 95:245.

Satter, L.D., and R.E. Roffler. 1975. Nitrogen requirement and utilization in dairy cattle. J. Dairy Sci. 58:1219.
Tilley, J.M.A., and R.A. Terry. 1963. A two-stage technique for the in vitro digestion of forage crops. J. Brit. Grassl. Soc. 18:104.

Torell, D.T., I.D. Hume, and W.C. Weir. 1972a. Flushing of range ewes by supplementation, drylot feeding, or grazing of improved pasture. J. Range Manage. 25:357.

Torell, D.T., I.D. Hume, and W.C. Weir. 1972b. Effect of level of protein and energy during flushing on lambing performance of range ewes. $J$. Anim. Sci. 34:479.

Van Dyne, G.M., and H.F. Heady. 1965. Botanical composition of sheep and cattle diets on a mature annual range. Hilgardia 36:465. 